\title{
Primary care quality and its effects on leprosy monitoring indicators
}

\author{
Qualidade da atenção primária e os efeitos em indicadores de monitoramento da hanseníase \\ Calidad de la atención primaria y los efectos en indicadores de monitoreo de la lepra
}

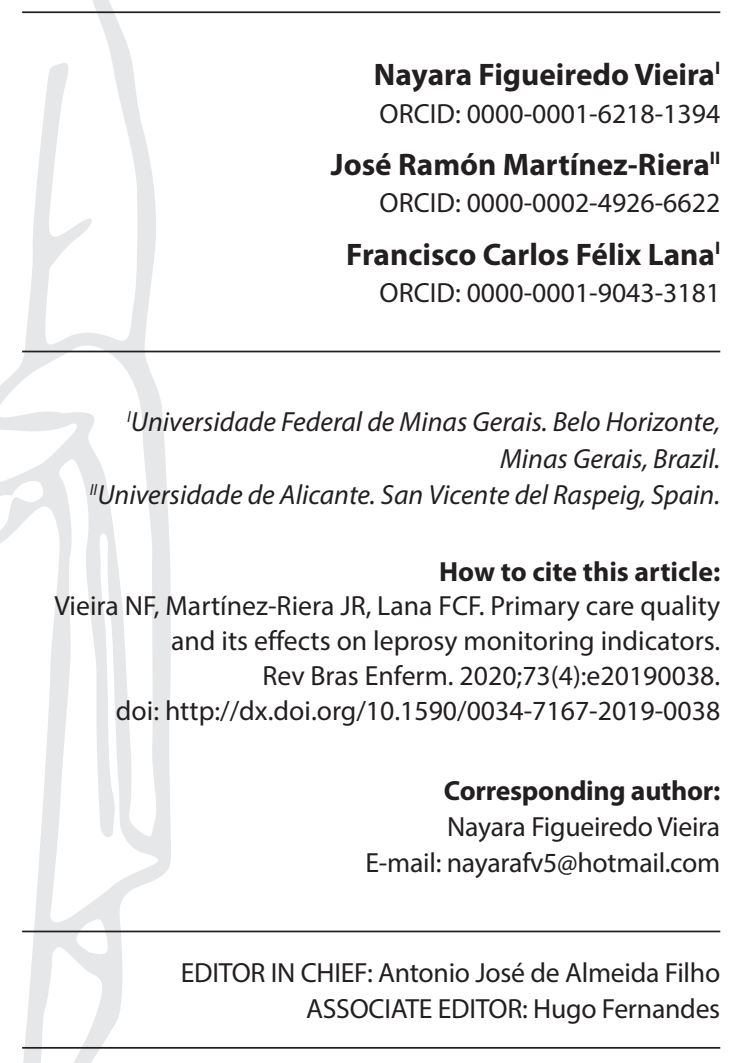

Submission: 01-21-2019

Approval: 09-17-2019

\begin{abstract}
Objectives: to evaluate the quality of primary care in leprosy control actions, to correlate effects on monitoring indicators. Methods: a cross-sectional study, conducted in Belo Horizonte, from July to September 2014. Interviews with 408 professionals were conducted through the application of a tool that assesses attributes of primary care in leprosy control actions, and monitoring indicators were calculated. Spearman correlation was used, significance level $p<0.05$. Results: the overall score correlated with the percentage of cases treated in primary care and of family health staff coverage. The derived score correlated with the percentage of cases treated in primary care, and the essential score correlated with the proportion and rate of cases diagnosed, with grade 2 physical disability. Conclusions: the quality of leprosy control actions performed by primary care professionals produces impacts on health indicators, and developing strategies consistent with the reality of the territory is necessary.

Descriptors: Health Evaluation; Nursing; Quality of Health Care; Leprosy; Primary Health Care.
\end{abstract}

\section{RESUMO}

Objetivos: avaliar a qualidade da atenção primária nas ações de controle da hanseníase e correlacionar efeitos em indicadores de monitoramento. Métodos: estudo transversal, realizado em Belo Horizonte, de julho a setembro de 2014. Entrevistaram-se 408 profissionais por meio da aplicação de ferramenta que avalia atributos da atenção primária nas ações de controle da hanseníase e calcularam-se indicadores de monitoramento. Utilizou-se correlação de Spearman, nível de significância $p<0,05$. Resultados: houve correlação entre escore geral e percentual de casos tratados na atenção primária e de cobertura de equipe de saúde da família. No escore derivado houve correlação com percentual de casos tratados na atenção primária e no essencial, com a proporção e taxa de diagnósticos com grau 2 de incapacidade física. Conclusões: a qualidade das ações de controle da hanseníase desempenhadas pelos profissionais da atenção primária impacta os indicadores de saúde, sendo necessárias estratégias condizentes com a realidade do território.

Descritores: Avaliação em Saúde; Enfermagem; Qualidade da Assistência à Saúde; Hanseníase; Atenção Primária à Saúde.

\section{RESUMEN}

Objetivos: evaluar la calidad de la atención primaria en las acciones de control de la lepra y correlacionarla con los efectos en indicadores de monitoreo. Métodos: estudio transversal, realizado en Belo Horizonte, entre julio y septiembre de 2014. Se entrevistaron 408 profesionales, por medio de la aplicación de la herramienta que evalúa los atributos de la atención primaria en las acciones de control de la lepra, y se calcularon los indicadores de monitoreo. Se utilizó la correlación de Spearman, con el nivel de significancia de $p<0,05$. Resultados: hubo una correlación entre la puntuación general y el porcentual de casos tratados en la atención primaria y de cobertura de equipo de salud de la familia. En la puntuación derivada hubo una correlación con el porcentual de casos tratados en la atención primaria, fundamentalmente con la proporción y tasa de casos diagnosticados, grado 2 de incapacidad física. Conclusiones: la calidad de las acciones de control de la lepra desempeñadas por los profesionales de la atención primaria produce impactos en los indicadores de salud, siendo necesario elaborar estrategias que concuerdan con la realidad del territorio.

Descriptores: Evaluación en Salud; Enfermería; Calidad de la Atención de Salud; Lepra; Atención Primaria de Salud. 


\section{INTRODUCTION}

In Brazil, high endemicity of neglected tropical diseases that have the relationship with poverty and misery in common persists, in addition to causing stigma and discrimination. Leprosy, an epidemiological infectious disease in the country, falls under this scenario $^{(1)}$. In epidemiological terms, Brazil has high endemicity (12.23 cases per 100,000 inhabitants). Moreover, indicators that reflect the quality of services, such as cure (81.74\%) and contact examinations (77.69\%), show the fragility of the leprosy control actions ( $\mathrm{ACH}$ - Ações de Controle da Hanseníase) ${ }^{(2)}$.

Faced with the need to strengthen the ACHs, the Brazilian Ministry of Health reinforces the recommendation for provision of continuing and complete healthcare by the primary health care (PHC) to cases, contacts, and families, coordinating the system according to the needs through mobilization actions to facilitate the diagnosis and reduce the stigma ${ }^{(3-5)}$.

Regarding the operationalization of the PHCs, the Family Health Strategy (FHS) is a priority for the consolidation of the care system ${ }^{(4)}$. The multidisciplinary composition of FHS shows favorable results concerning the care for leprosy patients, as well as improvement in the epidemiological situation and increased access to health services ${ }^{(6-8)}$.

Scientific evidences show health systems organized based on the $\mathrm{PHC}$ foundations are effective and have a good quality ${ }^{(9-10)}$. Its foundations are first contact accessibility, completeness, continuing care, coordination, and derivatives represented by community orientation and cultural competence ${ }^{(10)}$. One believes that the knowledge of the degree of orientation of the PHC on the leprosy actions can subsidize strategies to improve the service, thus contributing to control and elimination of the disease.

Studies evaluating the degree of orientation of the PHC on leprosy actions show the problems are related to the derived attributes (community and professional orientation), which are exactly the ones that improve the care for those affected by leprosy ${ }^{(11-13)}$. Other study showed the PHC has difficulty in performing actions related to turnover among professionals, lack of early detection of cases ${ }^{(7)}$, lack of knowledge of signs and symptoms ${ }^{(14)}$, negligence in the prioritization of disease on the part of political management ${ }^{(7)}$ and insufficient training ${ }^{(13,15-16)}$.

Despite the few records of studies evaluating the relationship between the epidemiological indicators and the quality of the $\mathrm{PHC}^{(7)}$, the integration of ACH into primary care can expand the access, enabling the strengthening of actions ${ }^{(17)}$. The barriers to the consolidation of the $\mathrm{PHC}$ as an encouraging factor prevent the eradication of the disease as a public health problem and, consequently, divert us from the goals proposed in the Global Leprosy Strategy 2016-2020(18).

Thus, assessing the primary care quality regarding the performance of the ACHs means to identify the weaknesses and strengths of the Unified Health System (SUS), because it enables determining the effectiveness of the care provided and its direct impact on the population's health ${ }^{(9,19-20)}$. Several evaluation studies focus on epidemiological trend analyses using the monitoring indicators $^{(3)}$ of epidemic recommended by the Ministry of Health ${ }^{(17,21-22)}$.

However, one highlights the study developed in a priority municipality in the Northeastern Brazil evaluating the temporal behavior of the monitoring indicators and assessing its relationship with the quality of leprosy services, showing significant association between the improvement in the indicators and the efforts to fight the epi$\operatorname{demic}^{(23)}$. The quality of the actions performed by the FHS has proven to influence the endemic scenario, and the way the care system is organized interfere in the work process, making it important to correlate the analysis of $\mathrm{PHC}$ with the epidemic situation ${ }^{(14,16)}$.

\section{OBJECTIVES}

To evaluate the quality of primary care in leprosy control actions and to correlate it with the effects on monitoring indicators, as a way of understanding the health-disease process and the determinants and conditionings of leprosy.

\section{METHODS}

\section{Ethical aspects}

This study is in accordance with the resolution No. 466, of December 12, 2012 and was approved by the Research Ethics Committee of the Universidade Federal de Minas Gerais under CAAE 24578213.2.0000.5149.

\section{Study design, location and period}

This is an evaluative cross-sectional observational study supported by the tool STROBE, conducted between July and September 2014 in Belo Horizonte, capital city of the state of Minas Gerais, Brazil. The conduction of this study is justified by the organization of the health care system and the complexity of the structure of services to meet the demands from population and territorial dimension. The average endemicity in the municipality for leprosy in 2016 was of 1.9 new cases per 100,000 inhabitants ${ }^{(3)}$.

\section{Population or sample: inclusion and exclusion criteria}

Due to the size of territory and population, the territory is divided into nine health districts (HD), in which 147 health centers are located. Health centers are administered by managers and subordinates of the district management; there are one or more FHS in the health centers. Thus, in the data collection period, $585 \mathrm{FHSs}$ were distributed disproportionately, by size and need of the territory.

A representative sample of the number of FHSs was estimated by calculating the proportion of teams for each $\mathrm{HD}$, and the total number of teams $(\mathrm{N}=585)$ was multiplied by the proportion found, obtaining $\Sigma=70 \mathrm{FHS}$. The criteria for inclusion of the health center was the place whose number of notifications of leprosy cases was the largest. This criterion was used because there were several FHSs in the health center selected, thus ensuring that professionals who were responsible or not for the cases were interviewed. The professional was expected to be ready for the follow-up of those affected by leprosy.

All managers working in the 147 health centers and in the 9 HDs were eligible. A total of 189 interviews were conducted, with 23 losses related to holidays, absence at the time of data collection, or medical leave.

For doctors, nurses and community health agents (ACS - Agente Comunitário de Saúde), as mentioned, a proportional sample was calculated. Regarding doctors and nurses, those who worked 
in the FHS were eligible; among them, 65 doctors (five losses, because professionals of theses teams missed in the last district) and 79 nurses were interviewed. For the community health agents, working for at least 12 months in the territory was the inclusion criterion, considering that these professionals have no specific training to work in the community and with the families. Therefore, seventy-five ACSs were interviewed.

\section{Study protocol}

The instrument for performance assessment in leprosy control actions by the PHC (PCAT-hanseníase) ${ }^{(12,19-20)}$ was used for evaluation of the quality of the $\mathrm{ACH}$ in the PHC. The tool was applied to managers, doctors, nurses, and ACSs through individual face-to-face interview in their work environment, after signing the informed consent form. Answers were given using the Likert scale, in which: 1 = strongly disagree, 2 = disagree, $3=$ agree, $4=$ strongly agree, $9=$ I don't know/l can't remember.

The calculation of the score of each attribute was based on the average: sum of the values of the answers to the items comprising each attribute divided by the number of items. The scores of respondents who answered "9" ("I don't know/I can't remember") for $50 \%$ or more of the questions were not calculated. The values of attributes with less than $50 \%$ of answers " 9 " were converted to "2" ("disagree"), so that the score of characteristics of the service the respondent did not know became negative ${ }^{(9,12)}$. Then, the scores were transformed into a scale from 0 to 10 by using the formula:

[score obtained- 1 (minimum value) $\times 10$

4 (maximum value)-1 (minimum value)

The overall result of the assessment using PCAT-hanseníase is composed of three measurements: the essential score, the average of essential attributes (access, encouraging factor, continuing care, coordination and completeness of the services provided and available); derived score, the average of the derived attributes (family, community and professional orientation); and overall score, average of the components of essential attributes plus the derived attributes, which characterizes the degree of orientation. The PHC was considered strongly oriented when the average was $\geq 6.6^{(9,12)}$. The outcome variables were the essential, derived, and overall score, because they allow evaluating the degree of orientation of the $\mathrm{PHC}$, thus enabling analyzing the quality of the $\mathrm{ACH}$.

Epidemiological and relevance indicators were selected from the conceptual viewpoint of the health-disease process for leprosy. The new cases of leprosy in Belo Horizonte from 2012 to 2016 notified in the Brazilian Disease Notification System (Sinan) were used for calculation of indicators. The calculation the average of the historical series is justified by the fact that the indicators oscillate slightly. Since data collection of the first phase occurred in 2014, the period selected was two years after and two years before.

Indicators recommended by the Ministry of Health were used: a. Annual Detection rate of new cases of leprosy per 100,000 inhabitants; b. Annual detection rate of new cases of leprosy, in the population from zero to 14 years old, per 100,000 inhabitants; c. Proportion of leprosy cases with grade 2 disability at the time of diagnosis among the new cases detected and assessed in the year; $d$. Rate of new leprosy cases with grade 2 disability at the time of diagnosis per 100,000 inhabitants ${ }^{(3)}$.

In addition to the indicators recommended, precepts of relevance were used, such as the percentage of family health assistance in 2014 - the year of data collection -, the percentage of the population living in areas of high and very high social risk in 2010 - because it was the last year assessed by the City Hall of Belo Horizonte -, and the percentage of new leprosy cases treated in the PHC, and of those notified.

\section{Analysis of results and statistics}

The analysis unit was the HD, and the data were analyzed and processed using the Statistical Package for the Social Sciences (SPSS) (version 19). Descriptive analysis and analytical technique were done. Spearman's Correlation was performed with a significance level of $5 \%(p<0.05)$.

\section{RESULTS}

Interviews were conducted with 408 professionals who worked in the primary care system in Belo Horizonte. Since the health district was the unit of analysis and the sample calculation was proportional, the number of teams per district was used as a basis, totaling: HD1 ( $=60), \mathrm{HD} 2(\mathrm{~N}=24), \mathrm{HD} 3(\mathrm{~N}=41), \mathrm{HD} 4(\mathrm{~N}=59)$, HD5 ( $\mathrm{N}=41), \mathrm{HD} 6(\mathrm{~N}=50), \mathrm{HD} 7(\mathrm{~N}=49)$, HD8 $(\mathrm{N}=28), \mathrm{HD} 9(\mathrm{~N}$ $=56$ ). Table 1 shows the essential, derived, and overall scores according to the experience of primary care professionals per HD.

By analyzing the essential score, strong orientation of the PHC in the actions of control of the disease ( $\geq 6.6)$ is observed. Weak orientation of the PHC was observed for the derived score in all the districts analyzed. Moreover, the professionals' perspectives varied. The overall score stood out by strong orientation selfreported by the participants ( $\geq 6.6$ ), which is converted into good quality in the actions performed. Table 2 describes the stratified monitoring indicators for the HD.

Table 2 shows that the population from HD6 lives in places of higher social risk and the territory with the greatest coverage of FHS is located in high-risk areas. In Belo Horizonte, less than $40 \%$ of cases are treated and notified in the PHC, with emphasis on the HD1, with the highest detection rate in the general population and in children. The HD1 is also responsible for most of cases of late diagnosis (rate and proportion of cases with grade 2 physical disability), when compared with the other districts. The HD7 shows the best results of performance indicators represented by the cure and examination of contacts.

In the overall score, the variables whose correlation was significant $(p<0.05$ ) were the percentage of cases treated in the $\mathrm{PHC}$ and the percentage of coverage of the FHS (rho $=-0.750$ ). Regarding the derived score, the correlation was significant ( $p$ $<0.05$ ) for the percentage of cases treated in the PHC (rho = 0.667). Moreover, in the essential score, the proportion of cases with grade 2 physical disability (rho $=-0.783$ ) correlated with the rate of cases with grade 2 disabilities (rho $=-0.767$ ). Figure 1 shows a scatterplot of the variables that showed statistical significance. 
Table 1 - Description of the essential, derived, and overall scores of primary care in leprosy control actions, from the perspective of health care professionals, Belo Horizonte, Minas Gerais, Brazil, 2014

\begin{tabular}{|c|c|c|c|c|c|c|c|c|c|}
\hline \multirow{3}{*}{$\begin{array}{l}\text { Health } \\
\text { District }\end{array}$} & \multicolumn{9}{|c|}{ Score } \\
\hline & \multicolumn{3}{|c|}{ Essential } & \multicolumn{3}{|c|}{ Derived } & \multicolumn{3}{|c|}{ Overall } \\
\hline & Mean & $\begin{array}{l}\text { Standard } \\
\text { deviation }\end{array}$ & $\begin{array}{l}\text { Minimum/ } \\
\text { Maximum }\end{array}$ & Mean & $\begin{array}{l}\text { Standard } \\
\text { deviation }\end{array}$ & $\begin{array}{l}\text { Minimum/ } \\
\text { Maximum }\end{array}$ & Mean & $\begin{array}{l}\text { Standard } \\
\text { deviation }\end{array}$ & $\begin{array}{l}\text { Minimum/ } \\
\text { Maximum }\end{array}$ \\
\hline 1 & 8.00 & 0.91 & $5.75 / 9.65$ & 4.81 & 2.33 & $0.00 / 9.23$ & 6.94 & 1.14 & $4.29 / 9.24$ \\
\hline 2 & 8.17 & 0.86 & $6.58 / 9.70$ & 6.29 & 1.79 & $2.22 / 10.00$ & 7.54 & 1.04 & $5.26 / 9.80$ \\
\hline 3 & 8.40 & 0.85 & $6.40 / 9.86$ & 4.79 & 2.46 & $0.00 / 8.24$ & 7.20 & 1.18 & $5.05 / 9.55$ \\
\hline 4 & 8.10 & 0.98 & $5.41 / 9.85$ & 5.23 & 2.33 & $0.56 / 8.96$ & 7.15 & 1.25 & $3.79 / 9.33$ \\
\hline 5 & 8.31 & 0.79 & $6.39 / 9.83$ & 4.59 & 2.07 & $0.00 / 9.44$ & 7.07 & 0.97 & $4.74 / 9.70$ \\
\hline 6 & 8.18 & 0.86 & $6.46 / 9.67$ & 4.90 & 2.33 & $0.00 / 9.17$ & 7.09 & 1.17 & $4.56 / 9.50$ \\
\hline 7 & 8.74 & 0.72 & 7.08/9.92 & 5.85 & 2.83 & $0.00 / 10.00$ & 7.78 & 1.24 & $5.14 / 9.78$ \\
\hline 8 & 8.22 & 0.52 & $6.55 / 9.26$ & 5.35 & 2.30 & $0.00 / 8.92$ & 7.26 & 0.88 & $5.32 / 8.75$ \\
\hline 9 & 8.31 & 0.69 & $6.80 / 9.72$ & 4.63 & 2.46 & $0.00 / 10.00$ & 7.08 & 1.08 & $4.95 / 9.45$ \\
\hline Total & 8.27 & 0.84 & $5.41 / 9.92$ & 5.08 & 2.40 & $0.00 / 10.00$ & 7.20 & 1.15 & $3.79 / 9.80$ \\
\hline
\end{tabular}

Table 2 - Description of the monitoring indicators of leprosy, Belo Horizonte, Minas Gerais, Brazil, 2017

\begin{tabular}{|c|c|c|c|c|c|c|c|c|c|c|}
\hline \multirow{2}{*}{$\begin{array}{l}\text { Health } \\
\text { District }\end{array}$} & \multicolumn{10}{|c|}{ Monitoring indicators } \\
\hline & A & B & C & D & $\mathbf{E}$ & $\mathbf{F}$ & G & $\mathbf{H}$ & $\mathbf{I}$ & $J$ \\
\hline 1 & 32.7 & 93.4 & 11.6 & 11.6 & 3.6 & 1.0 & 22.9 & 0.9 & 89.9 & 88.7 \\
\hline 2 & 20.1 & 34.1 & 58.3 & 49.2 & 1.5 & 0.5 & 16.7 & 0.3 & 79.3 & 67.9 \\
\hline 3 & 24.7 & 72.5 & 42.1 & 38.1 & 2.2 & 0.5 & 2.5 & 0.1 & 93.3 & 96.4 \\
\hline 4 & 27.4 & 81.6 & 38.5 & 42.5 & 2.3 & 0.0 & 18.8 & 0.4 & 92.2 & 88.0 \\
\hline 5 & 12.8 & 72.8 & 38.8 & 45.5 & 1.7 & 0.0 & 15.3 & 0.2 & 90.0 & 88.1 \\
\hline 6 & 47.4 & 96.8 & 48.5 & 49.6 & 2.1 & 0.4 & 13.5 & 0.3 & 85.1 & 79.8 \\
\hline 7 & 23.9 & 64.0 & 45.0 & 43.0 & 1.4 & 0.4 & 12.4 & 0.2 & 100.0 & 96.4 \\
\hline 8 & 16.4 & 59.7 & 50.4 & 58.0 & 2.1 & 0.5 & 5.0 & 0.1 & 88.3 & 86.9 \\
\hline 9 & 35.1 & 94.6 & 20.1 & 17.2 & 2.3 & 0.3 & 15.7 & 0.3 & 86.3 & 82.4 \\
\hline Total & 26.7 & 74.4 & 39.2 & 39.4 & 2.1 & 0.4 & 13.6 & 0.3 & 89.9 & 88.7 \\
\hline
\end{tabular}

Note: A. Percentage of the population living in areas of high and very high social risk: 2012 Health Vulnerability Index. Composite indicator consisting of issues related to sanitation, housing, education, income, social factors, environment. Source: City Hall of Belo Horizonte; B. Percentage of coverage of the family health team: proportion of the population of the federated unit assisted by the Family Health Strategy in 2014. Method of calculation: number of health teams $\times 3,000 \times 100 /$ resident population. Source: Department of Primary Care; C. Percentage of cases treated in primary care; ;. Percentage of cases notified in primary care*; E. Annual detection rate of new cases per 100,000 inh.*; F. Annual detection rate of new cases, in the population from zero to 14 years old, per 100,000 inh.* G. Proportion of leprosy cases with grade 2 physical disability at the time of diagnosis in the year*; $H$. Rate of new leprosy cases with grade 2 physical disability at the time of diagnosis per 100,000 inh.*; I. Proportion of cure of leprosy among new cases diagnosed in the years of the cohorts*; J. Proportion of examined contacts of new leprosy cases diagnosed in the years of the cohorts. *Indicators of leprosy, average from 2012 to 2016. Source: Brazilian Disease Notification System 


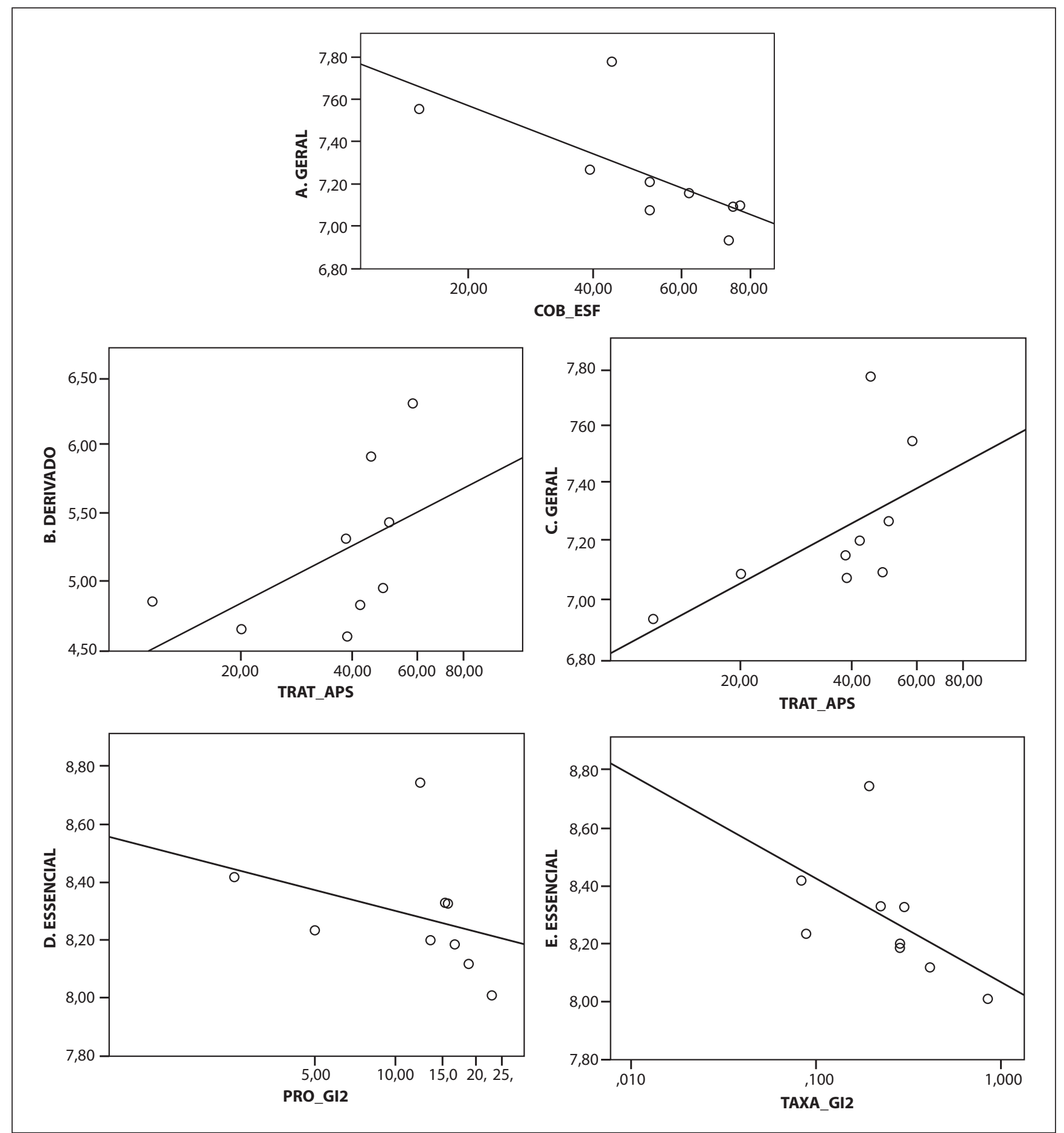

Note: A. Spearman's correlation between the overall score and the percentage of family health coverage. B. Spearman's correlation between the derived score and the percentage of leprosy cases treated in primary care. C. Spearman's correlation between the overall score and the percentage of leprosy cases treated in primary care. D. Spearman's correlation between the essential score and the proportion of new leprosy cases diagnosed with grade 2 physical disability. E. Spearman's correlation between the score and the rate of new leprosy cases with 2 grade 2 physical disability at the diagnosis per 100,000 inhabitants.

Figure 1 - Dispersion analysis of significant variables $(p<0.05)$ in the Spearman's correlation test

\section{DISCUSSION}

In Belo Horizonte, strong orientation of the $\mathrm{PHC}$ on the $\mathrm{ACH}$ in the overall score and significant correlation with the percentage of coverage of FHS and with the cases treated in primary care were observed. Strong orientation of the PHC was found for the essential score, as well as correlation with indicators that reflect the early diagnosis (detection of cases with grade 2 physical disability). However, the derived score had weak orientation of the $\mathrm{PHC}$ in the actions against the disease and correlated with the percentage of cases treated in primary care.

The FHS aims to organize the care model according to the principles of the SUS. It is a strategy for increased access, improvement and consolidation of the system and provides good 
cost-effectiveness ratio to the service ${ }^{(4)}$. The correlation between the coverage of the FHS and the overall score is a consequence of the prioritization established, in which greater coverage is found in places of the municipality where the social risk is higher.

Thus, the places where the coverage is greater are the HDs with high demand for assistance, because the worst socioeconomic conditions are found in the population of these areas, increasing the use of PHC services. The high number of socioeconomically disadvantaged populations shows the need for intersectoral investment for improving the population's living conditions, because the care provision by the FHS does not ensure the discovery of cases, requiring reflection on the social determinants of the disease $\mathrm{e}^{(8)}$. However, increased primary care provision helps in improving the monitoring indicators of leprosy ${ }^{(23)}$.

The PCAT-hanseníase is based on the theoretical framework of the $\mathrm{PHC}^{(10)}$ and on the $\mathrm{ACH}$ s recommended by the current policy ${ }^{(3)}$. In this context, studies using the PCAT-hanseníase found strong orientation of the $\mathrm{PHC}$ in the overall score, corroborating the findings of this study ${ }^{(11-13)}$. Therefore, primary care is the ideal scenario for the development of actions to promote the users' health, from the individual and collective viewpoint ${ }^{(14)}$.

The correlation between the overall score and derived score with the percentage of cases treated in the PHC shows the effectiveness of the service when performing the $\mathrm{ACH}$, because the quality of the care is better when the professional followup is conducted in the primary care. In Brazil, for decades, the care for those affected by leprosy was provided by specialized units, with leprologists and dermatologists ${ }^{(5)}$, and focused on biomedical aspects, increasing the stigma and diverting us from the comprehensive vision of care.

However, studies show the integration of leprosy into the primary care is a strategy capable of increasing the access, which enables incorporating the early detection actions and improving the care ${ }^{(8,14,24-26)}$. One believes that the strengthening of $\mathrm{ACH}$ in the primary health care improves the early detection of cases through health surveillance carried out in the units, and thus contributes to reduction in physical disabilities caused by the disease and decrease in stigma.

Concerning the derived score composed of qualifier attributes (community, family and professional orientation) of the service, variability in the HDs was observed, highlighting the weak orientation of the PHC on the performance of control actions of the disease. The uneven performance indicates that demographic, social and epidemiological issues may influence the quality of the services ${ }^{(23)}$. Regarding the epidemiological aspects of the disease, its heterogeneous distribution is observed in the Brazilian territory ${ }^{(22)}$. In this context, mobilizing public health policies to promote the reduction in economic, social and health inequalities is necessary ${ }^{(8)}$.

An international experiment has shown the importance of the political commitment to the development of the disease control program, of the universal provision of polychemotherapy, of the training of professionals and of the advice to leprosy patients, factors contributing to the eradication of the epidemic ${ }^{(27)}$.

Furthermore, the importance of focusing on family care and community orientation, resulting in better health outcomes for the population, can be highlighted as a way to strengthen the derived attributes ${ }^{(28-29)}$. Considering that family-oriented health consists of assessing the individual needs for a comprehensive care, one should consider the family context and its care potential. Community orientation consists of the recognition of the needs of the community on the part of the service through epidemiological data and direct contact with the community ${ }^{(10)}$.

Studies on community orientation suggest the teams have difficulty in performing activities such as assessment of the epidemiological situation to plan actions, active search of cases, intersectoral partnerships and educational interventions ${ }^{(30)}$ to inform the community about the signs and symptoms of the disease ${ }^{(7,15,31)}$. Highlighting that problems regarding community orientation is not limited to leprosy becomes appropriate; a study conducted in Belo Horizonte assessing the PHC also found weak orientation in services in general ${ }^{(32)}$.

Thus, redistributing tasks of the FHS in the territory is needed, as well as training managers, doctors, nurses, ACSs and community regarding the recognition of the needs of the territory, promoting active mobilization and social control.

Family-oriented care proves to be powerful for improvement in the care for leprosy patients, since the patients' family is the group likely to have the disease. The support from family when treating leprosy is paramount to the achievement of positive results, once it helps in understanding the health-disease process and adhering to drug therapy, strengthening the health surveillance ${ }^{(14)}$. However, studies show the incorporation of the family into care practices is still incipient, and patients realize little or no interest from FHS professionals in their living conditions and families ${ }^{(28-29)}$.

Regarding the essential score, strong orientation of the PHC to leprosy was observed. This score consists of a component related to the structure and the process of care, for example, the access composed of the component accessibility (structure) and the component use (process) ${ }^{(9)}$. In this study, Spearman's correlation was found between the essential score and the proportion and rate of new leprosy cases with grade 2 physical disability at the diagnosis. The cases diagnosed with grade 2 physical disability were used to assess the effectiveness of the activities of opportunistic and/or early detection, and the HDs had high proportion of late diagnosis $(\geq 10)^{(3)}$. The essential score is composed of the attributes encouraging factor, access, completeness, coordination and continuing care, which are dimensions related to opportunistic detection of cases.

Actions such as programs developed by health services, educational interventions, comprehensive coverage of disease control actions and competence of health professionals for accurate and early diagnosis are strategies to eradicate and control leprosy ${ }^{(24)}$.

The diagnosis is clinical and when the frequency of the disease is low, it becomes unfamiliar to doctors, who tend not to consider it among the possible diagnoses when faced with a probable case. This contributes to more delay in diagnosis and leads to further worsening of the disease ${ }^{(1)}$. Considering that, studies have shown the importance of the training aimed at professionals working in primary care, such as ACSs, not only at doctors and nurses ${ }^{(13,16)}$. One believes that professional qualification can modify an epidemiological situation regarding the $\mathrm{ACH}$, because such measure encourages a distinguished look at the performance leprosy control actions. 


\section{Study limitations}

The limitations are that data collection was performed on only one municipality, which restricts making generalizations, bur provides an approximation between the quality of care and health indicators.

\section{Contributions to the area of Nursing, Health or Public Policy}

This study contributes in order to demonstrate that the quality of care provide by health services has effects on leprosy monitoring indicators. Thus, managers must plan health actions in order to strengthen the qualification of family health teams and increase the surveillance actions carried out in the care territories.

\section{CONCLUSIONS}

The conclusion is that the quality of leprosy control actions performed by primary care professionals produces effects on the monitoring indicators of the disease. In addition, health surveillance should integrate individual and collective practices in different dimensions of health needs of those affected by leprosy, which include the control of risks, the discussion of social determinants of health and the planning of actions in line with the reality of the territory.

The evidences observed show the relevance of ongoing assessments in health services, because the latter are influenced by political, economic and social contexts of the country. One believes in the potential of PHC for a good quality care for patients with a disease such as leprosy, focusing on comprehensive care and considering the context in which he/she is placed.

\section{FUNDING}

Ministry of health- Department of Health Surveillance, through the public notice 197/2012.

Fundação de Amparo à Pesquisa do Estado de Minas Gerais (Fapemig), through the public notice 03/2014.

\section{REFERENCES}

1. Segurado AC, Cassenote AJ, Luna EA. Saúde nas metrópoles: doenças infecciosas. Estud Av [Internet]. 2016;30(86):29-49. doi: 10.1590/ S0103-40142016.00100003

2. World Health Organization. Department of Control Neglected Tropical Diseases. Global leprosy update, 2017: reducing the disease burden due to leprosy. WER [Internet]. 2018 [cited 2018 Jan 7];93(35):445-56. Available from: https://www.who.int/wer/2018/wer9335/en/

3. Ministério da Saúde (BR). Portaria no 149, de 3 de fevereiro de 2016. Aprova as diretrizes para vigilância, atenção e eliminação da hanseníase como problema de saúde pública, com a finalidade de orientar os gestores e os profissionais dos serviços de saúde. Diário Oficial da União [Internet]. 2016[cited 2017 Mar 25];84(1):121. Available from: http://bvsms.saude.gov.br/bvs/saudelegis/gm/2016/prt0149_04_02_2016.html

4. Ministério da Saúde (BR). Portaria n².436, de 21 de setembro de 2017. Aprova a Política Nacional de Atenção Básica, estabelecendo a revisão de diretrizes para a organização da Atenção Básica, no âmbito do Sistema Único de Saúde (SUS). Diário Oficial da União [Internet]. 2017 Sept 22 [cited 2019 Jan 7];183(1):68. Available from: http://bvsms.saude.gov.br/bvs/saudelegis/gm/2017/prt2436_22_09_2017.html

5. Savassi LCM, Modena CM. Hanseníase e a atenção primária: desafios educacionais e assistenciais na perspectiva de médicos residentes. Hansen Int [Internet]. 2015 [cited 2017 Aug 15];40(2):2-16. Available from: http://www.ilsl.br/revista/detalhe_artigo.php?id=12359

6. Moreira ESM, Barbosa NB. Fisioterapia na atenção primária em saúde - o processo de implantação dos NASF em Anápolis-Goiás. Rev Educ Saúde [Internet]. 2016 [cited 2017 Jul 1];4(1):26-34. Available from: http://revistas.unievangelica.edu.br/index.php/educacaoemsaude/ article/view/1692/1548

7. Saltarelli RMF, Seixas DHT. Limites e possibilidades na atenção ao portador de hanseníase no âmbito da estratégia saúde da família. Rev APS [Internet]. 2016 [cited 2017 Aug 17];19(4):613-22. Available from: https://aps.ufjf.emnuvens.com.br/aps/article/view/2443/1041

8. Monteiro LD, Mota RMS, Martins-Melo FR, Alencar CH, Heukelbach J. Social determinants of leprosy in a hyperendemic State in North Brazil. Rev Saúde Pública. 2017;(51):1-11. doi: 10.1590/s1518-8787.2017051006655

9. Ministério da Saúde (BR). Manual do instrumento de avaliação da atenção primária à saúde: Primary Care Assessment Tool PCATool-Brasil [Internet]. Brasília: Ministério da Saúde; 2010 [cited 2018 Jun 9]. Available from: http://bibliotecadigital.puc-campinas.edu.br/services/ebooks/manual_avaliacao_pcatool_brasil.pdf

10. Starfield B. Atenção primária: equilíbrio entre necessidades de saúde, serviços e tecnologia. Brasília: Unesco; 2002.

11. Vieira NF, Lanza FM, Lana FCF, Martínez-Riera JR. Assessment of the attributes of primary health care in leprosy control actions. Rev Enferm UERJ. 2018;26:e31925. doi: 10.12957/reuerj.2018.31925

12. Lanza FM. Avaliação da atenção primária no controle da hanseníase: validação de instrumento e análise de desempenho de municípios endêmicos de Estado de Minas Gerais [Tese]. Belo Horizonte: Universidade Federal de Minas Gerais; 2014.

13. Sousa GS, Silva RLF, Xavier MB. Atributos da atenção primária em saúde no controle da hanseníase: ótica do enfermeiro. Rev Baiana Enferm. 2017;31(1):1-10. doi: 10.18471/rbe.v31i1.17251

14. Ribeiro MDA, Castillo IS, Silva JCA, Oliveira SB. The nurse's view on leprosy treatment in primary health care. Rev Bras Promoç Saúde. 2017;30(2):221-28. doi: 10.5020/18061230.2017.p221

15. Sousa GS, Silva RLF, Xavier MB. Hanseníase e Atenção Primária à Saúde: uma avaliação de estrutura do programa. Saúde Debate. 2017;41(112):230-42. doi: 10.1590/0103-1104201711219 
16. Girão Neta OA, Arruda GMMS, Carvalho MMB, Gadelha RRM. Health professionals' and managers' perception of leprosy care within the family health strategy. Rev Bras Promoç Saúde. 2017;30(2):239-48. doi: 10.1590/1980-5497201700040013

17. Gomes FBFF, Lana FCF, Oliveira RC, Rodrigues RN. Indicators of leprosy in the state of Minas Gerais and its relationship with the municipal human development index and the coverage of the family health strategy. Rev Min Enferm. 2017;21:e-1063. doi: $10.5935 / 1415-2762.20170073$

18. World Health Organization. Department of Control Neglected Tropical Diseases. Global Leprosy Strategy 2016-2020: accelerating towards a leprosy-free world [Internet]. New Delhi:WHO; 2016 [cited 2018 Dec 20]. Available from: http://apps.searo.who.int/PDS_DOCS/B5233.pdf

19. Lanza FM, Vieira NF, Oliveira MMC, Lana FCF. Instrumento para avaliação das ações de controle da hanseníase na Atenção Primária. Rev Bras Enferm. 2014;67(3):339-46. doi: 10.5935/0034-7167.20140044

20. Lanza FM, Vieira NF, Oliveira MMC, Lana FCF. Evaluation of leprosy control actions developed in primary care: a proposed tool for managers. Rev Min Enferm. 2014;18(3):606-13. doi: 10.5935/1415-2762.20140044

21. Araújo KMFA, Leano HAM, Rodrigues RN, Bueno IC, Lana FCF. Tendência de indicadores epidemiológicos da hanseníase em um estado endêmico. Rev Rene. 2017;18(6):771-8. doi: 10.15253/2175-6783.2017000600010

22. Schneider PB, Freitas BHBM. Tendência da hanseníase em menores de 15 anos no Brasil, 2001-2016. Cad. Saúde Pública. 2018;34(3):e00101817. doi: 10.1590/0102-311X00101817

23. Souza CDF, Matos TS. Análise de tendência dos indicadores de monitoramento e avaliação da qualidade dos serviços de hanseníase em município prioritário do Nordeste brasileiro. Rev Bras Pesqui Saúde [Internet]. 2017 [cited 2018 Nov 03];19(4):75-83. Available from: http:// periodicos.ufes.br/RBPS/article/view/19806/13228

24. Oliveira LB, Alves ES, Araújo TME, Melo IV, Araújo RPS, Marques LMF. Epidemiological profile of leprosy in a municipality in the Brazilian Northeast: a retrospective analysis. Rev Pesqui Cuid Fundam. 2017;9(3):648-52. doi: 10.9789/2175-5361.2017.v9i3.648-652

25. Ribeiro GC, Lana FCF. Physical disabilities in leprosy: characterization, factors related and evolution. Cogitare Enferm [Internet]. 2015 [cited 2017 May 2];20(3):495-502. Available from: http://docs.bvsalud.org/biblioref/2016/08/1159/41246-162514-1-pb.pdf

26. Rodrigues FF, Calou CGP, Leandro TA, Antezana FJ, Pinheiro AKB, Silva VM, et al. Knowledge and practice of the nurse about leprosy: actions of control and elimination. Rev Bras Enferm. 2015;68(2):271-7. doi: 10.1590/0034-7167.2015680216i

27. Al-Awaidy ST. Progress towards a leprosy-free country: the experience of Oman. Plos Negl Trop Dis. 2017;11(11):e0006028. doi: 10.1371/ journal.pntd.0006028

28. Alencar MN, Coimbra LC, Morais APP, Silva AAM, Pinheiro SRA, Queiroz RCS. Avaliação do enfoque familiar e orientação para a comunidade na Estratégia Saúde da Família. Ciênc Saúde Colet. 2014;19(2):353-64. doi: 10.1590/1413-81232014192.08522012

29. Silva NC, Giovanella L, Mainbourg EMT. A família nas práticas das equipes de Saúde da família. Rev Bras Enferm. 2014;67(2):274-81. doi: 10.5935/0034-7167.20140037

30. Muthuvel T, Govindarajulu S, Isaakidis P, Shewade HD, Rokade V, Singh R, et al. "I wasted 3 years, thinking it's not a problem": patient and health system delays in diagnosis of leprosy in India: a mixed-methods study. Plos Negl Trop Dis. 2017;11(1):e0005192. doi: 10.1371/journal. pntd.0005192

31. Silva LSR, Silva TM, Rocha JT, Andrade WG, Lessa EC, Correia NS. Nursing care for leprosy patients assisted by the family health program. Rev Enferm UFPE. 2016;10(11):4111-7. doi: 10.5205/reuol.9881-87554-1-EDSM1011201637

32. Turci MA, Lima-Costa MF, Macinko J. Influência de fatores estruturais e organizacionais no desempenho da atenção primária à saúde em Belo Horizonte, Minas Gerais, Brasil, na avaliação de gestores e enfermeiros. Cad Saúde Pública. 2015;31(9):1941-52. doi: 10.1590/0102-311X00132114 